\title{
Testudo cf. graeca from the new Late Miocene locality of Platania (Drama basin, N. Greece) and a reappraisal of previously published specimens
}

\author{
Vlachos E..$^{*}$, Tsoukala E..$^{*}$ \\ ${ }^{1}$ Corresponding author \\ *School of Geology, Aristotle University of Thessaloniki, University Campus, 54124, Greece, \\ evlacho@geo.auth.gr, lilits@geo.auth.gr
}

\begin{abstract}
In this paper we describe a new Neogene mammalian site and one of the latest discoveries of a fossil tortoise in Greece, from Platania locality, in Drama basin, Northern Greece. The preliminary study of the numerous fossil mammal remains shows that the recovered fauna is of Late Miocene age. The tortoise material consists of a partial shell and a limb bone that belong to the same individual. They are attributed to the Testudo cf. graeca, and are members of the Testudo s.s. lineage, characterized by the presence of a hypo-xiphiplastral hinge. This new material indicates that the presence of $T$. graeca in Greece could expand into the Late Miocene. Comparisons with other fossils of the genus Testudo s.s. from Greece, allowed the revision of previously published specimens of $T$. graeca.
\end{abstract}

Key words: Testudo s.s., turtle, hinge. Neogene

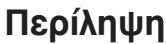

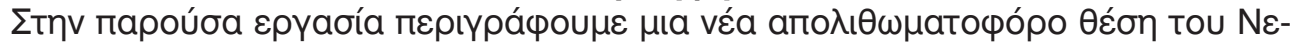

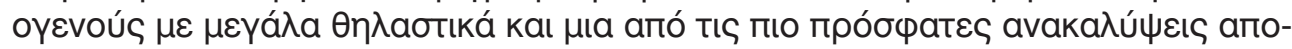

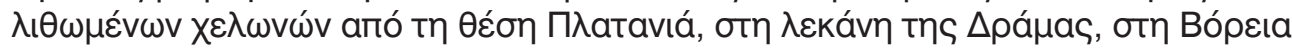

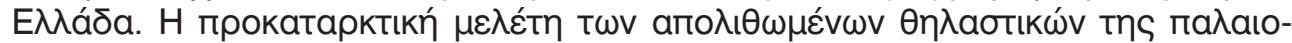

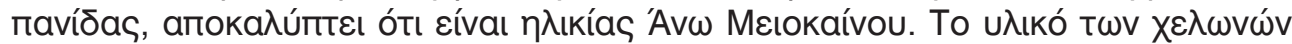

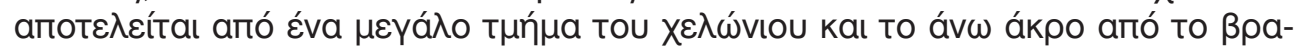

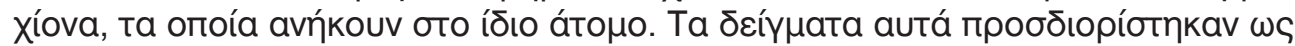

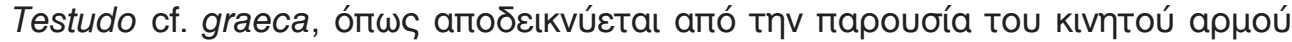

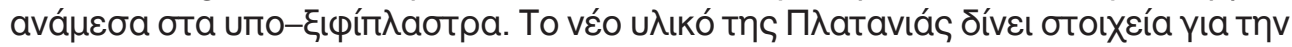

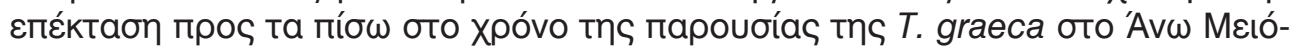

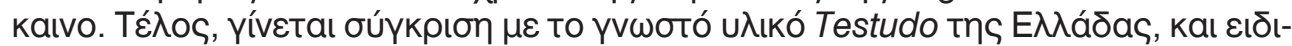

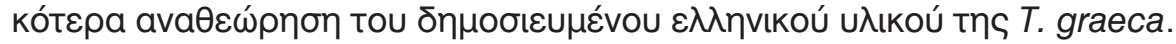

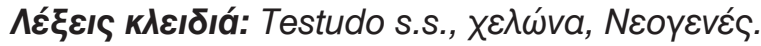

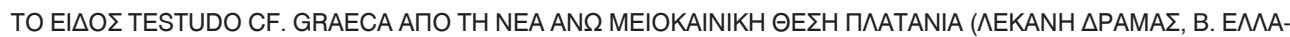
$\triangle$ A) KAI MIA EПANEKTIMH $\Sigma$ H ПPOHГOYMENA $\triangle H M O \Sigma I E Y M E N \Omega N ~ A T O M \Omega N$.

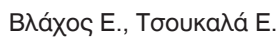




\section{Introduction}

Platania village is located in the Drama basin, Northern Greece. It is situated about $30 \mathrm{Km}$ northeastern of Drama city in Eastern Macedonia. Administratively, it belongs to the Municipality of Paranesti. From this area, a new vertebrate fossil locality, named Platania, joins a list of few fossil sites in Drama basin. The youngest is the Late Pleistocene (Würmian) locality on the banks of Aggitis river, near the Maaras cave, with findings of typical Late Pleistocene mammal species (Koufos, 1981; Trantalidou, 2013). The remaining sites are: the Early Pleistocene site of Volax, with a diverse mammal fauna (Koufos and Vlachou, 1997; Kostopoulos, 1997; and references therein); the Pliocene locality of Kalliphyto, with a mandible finding of Anancus arvernensis (Athanasiou, in press). The closest to Platania known Late Miocene locality is the Thermopigi site, located in a nearby basin, the Serres basin (Geraads et al., 2007).

Fossil turtles and tortoises are not common elements in Greek fossil localities, producing nevertheless a decent fossil record that has been poorly studied up to now (see Comparisons). In this paper, we focus on the fossil Mediterranean spur-thighed tortoise, Testudo graeca Linnaeus, 1758, a taxon that still survives today in Greece, together with other terrestrial taxa like "Testudo" hermanni Gmelin, 1789 and Testudo marginata Schoepff, 1792. The fossil record of $T$. graeca, however is rather poor: it has been discovered in very few Greek localities so far, such as Megalo EmvoIon, near Thessaloniki (Pliocene, Bachmayer et al., 1979) and Lesvos island (Early Pleistocene, as Testudo cf. graeca ibera, Lapparent de Broin, 2002). But since many testudinid specimens have only been mentioned in the litera- ture and never been formally described, the true range of this taxon in Greece could be much greater than previously thought. For example, Garcia et al. (2011) preliminary reported a new testudinid from the Vallesian (MN10) locality Ravin de la Pluie (lower Axios valley, N. Greece).

Here, we announce the discovery of the Platania fossil locality and we describe the single tortoise finding from this site. This is one of the few Late Miocene testudinid remains from Greece, and the first from Drama basin. Its study contributes significantly to our knowledge of the Greek fossil chelonians, and especially to those specimens which have been associated with Testudo graeca.

Anatomical Abbreviations: Bony plates are indicated with small letters, scutes with capitals. ABD, abdominal; AN, anal; cos, costal; en, entoplastron; ep, epiplastron; FE, femoral; GU, gular; hyo, hyoplastron; hypo, hypoplastron; $\mathrm{HU}$, humeral; MA, marginal; nu, nuchal; PEC, pectoral; per, peripheral; VE, vertebral; xi, xiphiplastron.

Institutional Abbreviations: AMPG, Museum of Palaeontology and Geology of the National and Kapodistrian University of Athens, Greece; IGF, Institute of Geology, Florence, Italy; LGPUT, Laboratory of Geology and Paleontology, University of Thessaloniki, Greece; MNHN, Muséum National d'Histoire $\mathrm{Na}$ turelle, Paris, France; NHMW, Naturhistorisches Museum, Vienna, Austria.

Other Abbreviations: a.s.l., above sea level; E.G.S.A., Greek Geodetic Reference System; PLD, Platania, Drama.

\section{Locality Information}

The Platania locality has been discovered following information by local people (K. Eleftheriadis and M. Kagiaoglou) 
to the archaeologist V. Puliudi, as a result of mud collection in the area to build an outdoor mud oven. The fossiliferous site (Fig. 1A, 1C,) is an exposed slope that was artificially opened during rural road construction, near Platania village (N410 11' 48.4"', E024 23' 42.0'", elevation is $257 \mathrm{~m}$ a.s.I., Hellenic Grid, EGSA '87). The fossils were recovered disarticulated and they show a characteristic blackish color (Fig. 1B) that is related to presence of high manganese (Mn) concentrations during fossilization processes (I. M. Zougrou, pers. comm.).

The sediments cover the lower parts of this sub-basin, which consists of alternations of high metamorphic Paleozoic rocks, such as gneisses, mica schists, marbles, which belong to the Rhodope massif (Fig. 1C, based on Krinidhes sheet, 1:50.000; N.I.G.M.R., 1974; mapping by $P$. Kronberg, 1962-1970). The fossiliferous site consists mainly of sands and muds, forming two main layers (Fig. 1D). The upper layer consists of consolidated red-brown clayish-sands, with parts that show typical cross-bedding structure. The lower layer with fossils in the lower part is brownish and consists mainly of fine sand with some mud. In this section two layers of conglomerates are distinguished: one consolidated, between the two main layers, and the other thinner, located just above the fossils. These deposits indicate a fluvial environment. Few meters above the fossiliferous site, another outcrop is exposed, representing the deposits just above the PLD section, which are mainly finelayered yellow-brownish muds, indicating a more lacustrine environment. The fossils, due to their black color, are easily recognizable in the light colored sediments. The first fossils were delivered to one of us (ET), and several vis- its on the site followed, before the July 2013 excavation. The fossils were excavated using standard rules, where the positional data (azimuth, dip, position) have been recorded. The preliminary study of the mammalian fossils (ET and collaborators, under preparation) has revealed the presence of hipparions, giraffes, rhinoceroses, mastodons, bovids, suids, represented by skulls, mandibles and many complete appendicular elements. The recovered assemblage, in relation with the regional stratigraphy, points out to a Late Miocene age.

\section{Material and Methods}

The fossil material is stored at the collections of LGPUT, under the inventory numbers LGPUT PLD 70 and 71. The material was compared with similar testudinids from Greece, housed at AMPG, IGF, LGPUT, MNHN, and NHMW. Due to the black color of the fossil specimens recovered from Platania, in order to facilitate the reader, the digital photographs have been partially corrected using the Curves command in Adobe Photoshop CS5. Shell nomenclature follows Zangerl (1969). Taxonomy follows Joyce et al. (2004).

\section{Palaeontology}

TESTUDINES Batsch, 1788

CRYPTODIRA Cope, 1868

TESTUDINIDAE Gray, 1825

Testudo cf. graeca Linnaeus, 1758

Material: LGPUT PLD 70, partial shell (Figs 2-3); LGPUT PLD 71, right humerus, proximal part (Fig. 4).

Description: This partial shell consists of the anterior carapacial margin and the right bridge, the left posterior carapacial margin and most of the plastron. 


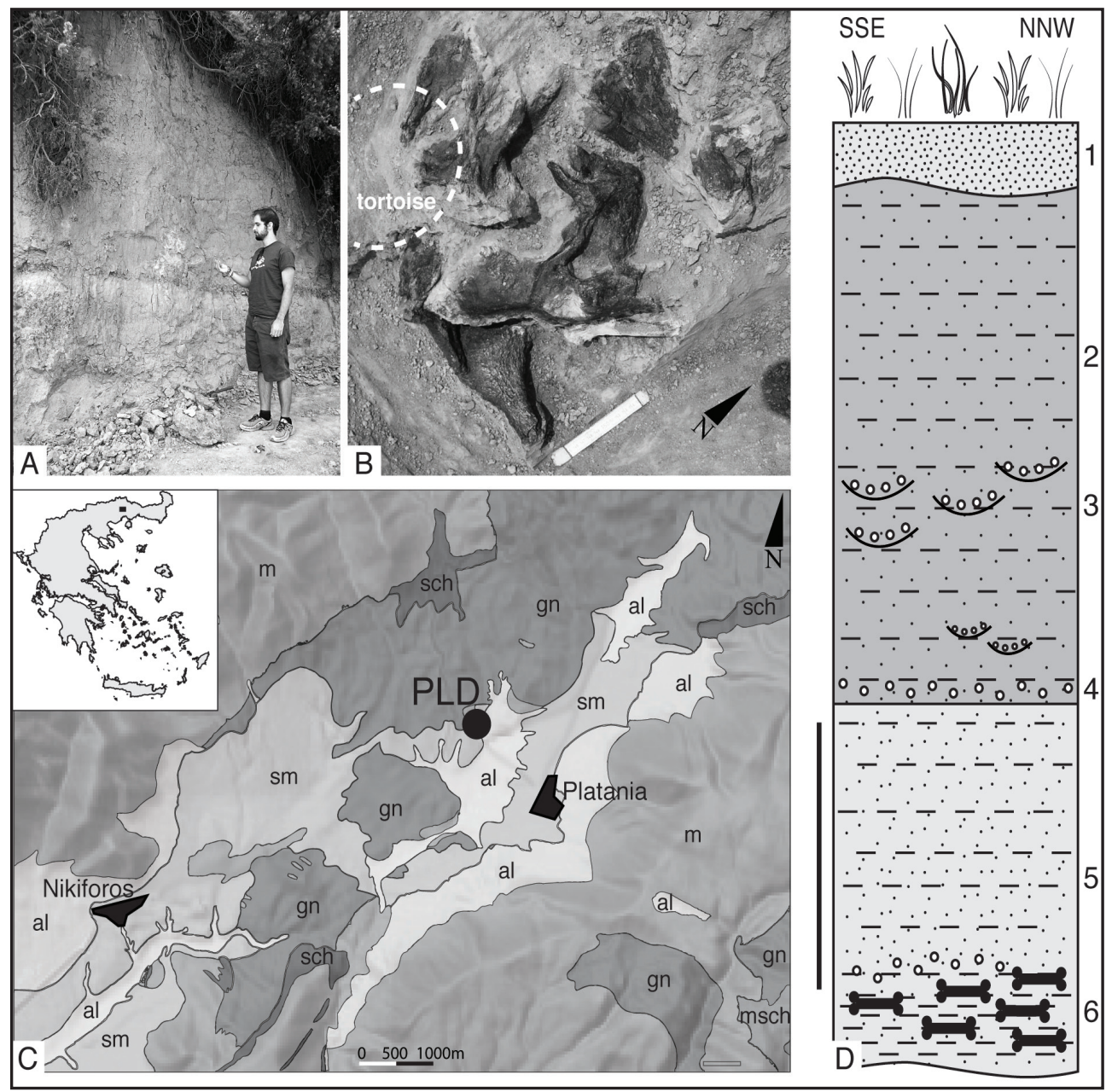

Fig. 1. The new Late Miocene locality of Planatia, Drama basin, Northern Greece. A, photograph of the site. $B$, the fossils in recovery position, the dotted line indicating the position of the tortoise finding below an hipparion skull, scale bar equals $10 \mathrm{~cm}$. C, simplified geological map of the area (based on Krinidhes sheet, 1:50.000; N.I.G.M.R., 1974; mapping by P. Kronberg, 1962-1970) and map of Greece with the Platania site depicted. $D$, simplified stratigraphic column of the Platania locality, scale bar equals $1 \mathrm{~m}$. Legend for the geological map: al, Holocene-Quaternary terrestrial and alluvial deposits; gn, gneisses and gneiss-schists; m, marbles; msch, marbles and micaschists; sch, micaschists; sm, Neogene clays, sands, and gravels. Legend for the stratigraphic column: 1, soil; 2, red-brown clayish-sands; 3, cross-bedding; 4, conglomerate; 5, brownish sands and muds; 6, fossils.

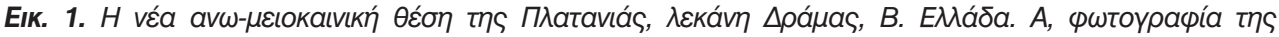

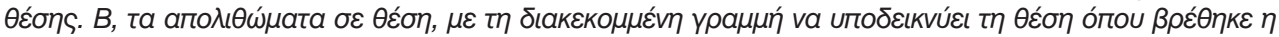

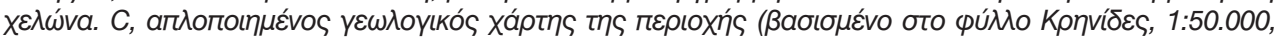

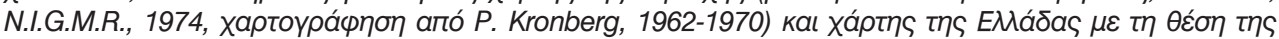

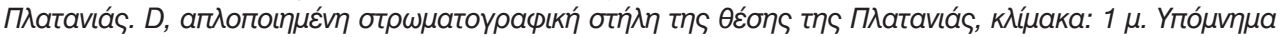

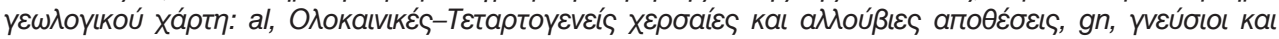

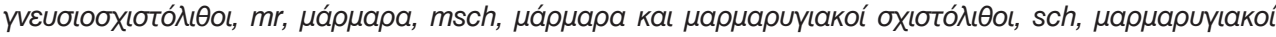

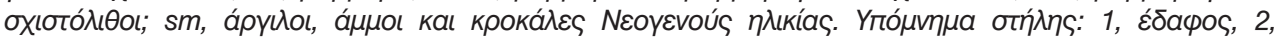

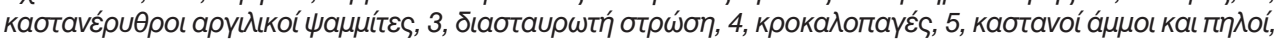

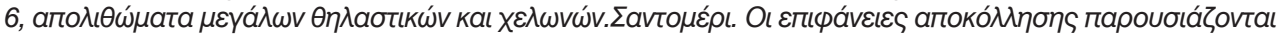

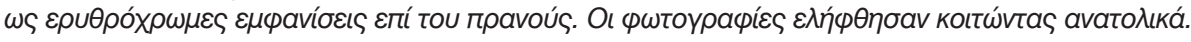


The right xiphiplastron is missing.

This specimen has been recovered in natural position, but the visceral side of the plastron is eroded and almost empty of appendicular elements. The only exception is a partial right humerus, found inside this specimen. Moreover, all the breaks of the carapace are ei- ther on sutural surfaces, or are eroded. Based on the above, we assume that the shell has undergone some modification prior to burial, but only for a short period. This is because the mobile xiphiplastra, which are connected with the plastron with a hinge, were not found disarticulated.

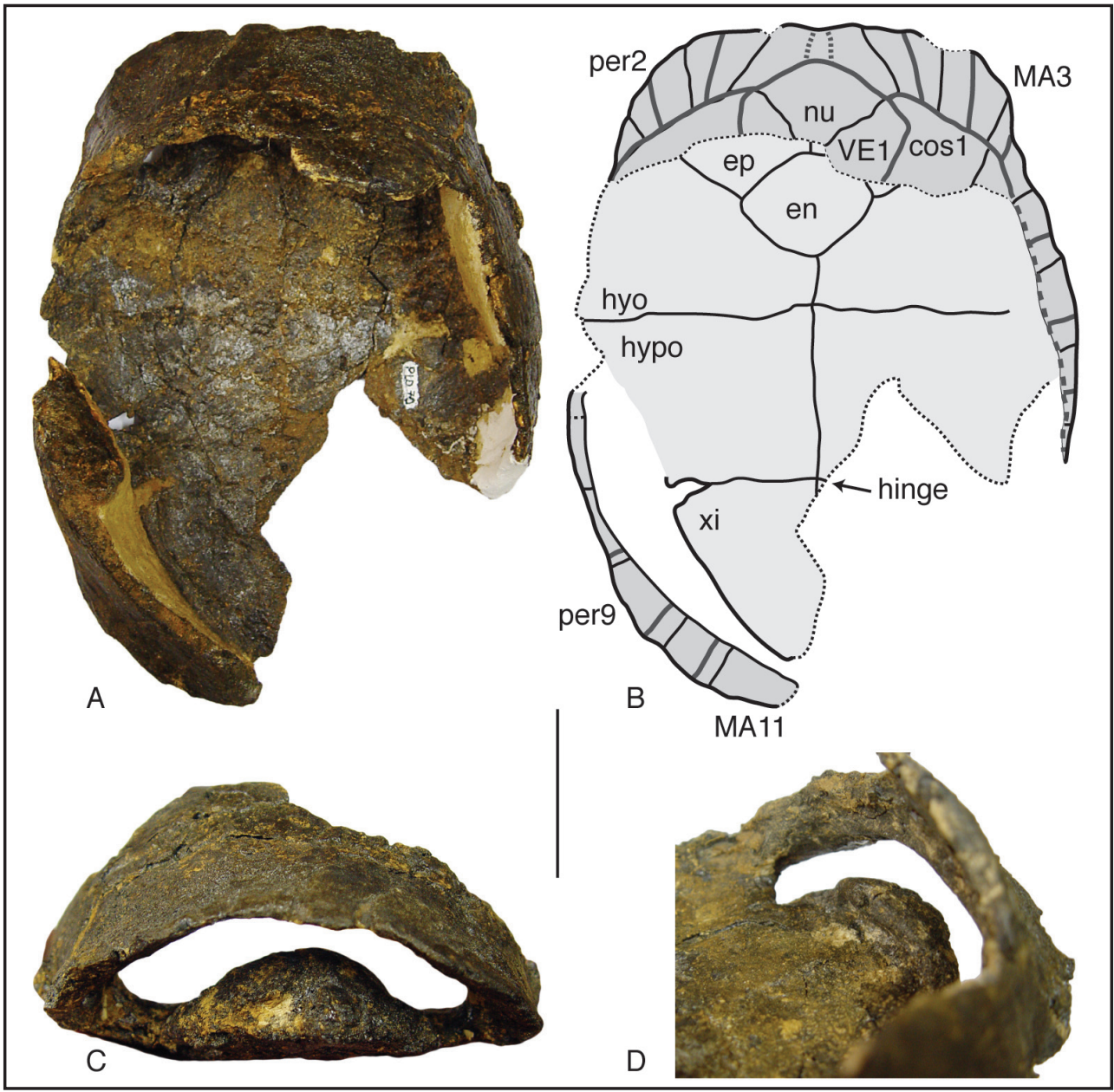

Fig. 2. The partial shell of the specimen of Testudo cf. graeca (LGPUT PLD 70) from the Late Miocene of Platania (Drama basin, Northern Greece),. A, partial carapace and plastron in dorsal view. B, drawing of the dorsal view. Sutures are indicated with black lines, sulci with grey lines. $C$, anterior view. $D$, dorso-lateral view of the right side, showing the epiplastral lip. Scale bar equals $5 \mathrm{~cm}$.

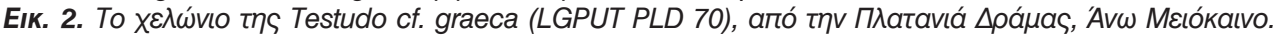

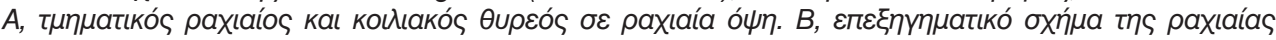

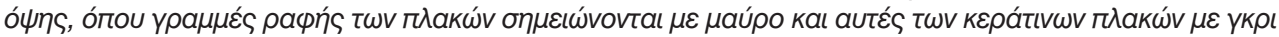

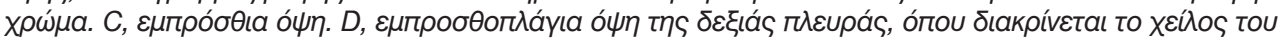

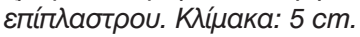


Carapace: From the carapace (LGPUT PLD 70), the anterior margin with the nuchal is preserved with most of the right bridge, i.e. from the partial 3 rd left till the anterior region of the 7th right peripheral (Fig. 2A). The nuchal is hexagonal in shape, with a narrow posterior part. Anteriorly, a very weak and wide, almost non-existent, nuchal notch is present. Only some parts of the left and right 1st costals are preserved. Posteriorly, only the left carapacial margin is preserved, from the 6th to 11th peripheral. Anterior and posterior peripherals are long and narrow, whereas those from the bridge area are much taller. From the shape of the 11th peripheral we can estimate that the pygal is trapezoid in shape, with narrower posterior end. Based on the curved shape of the preserved 11th peripheral, we can assume that the pygal was also curved inwards. This is commonly found in Testudo graeca and "Testudo" hermanni (both in males and females), but not in Testudo marginata, where the pygal is posteriorly flared. The nuchal is crossed by the vertebro-marginal sulcus in the anterior part and, despite the fact the anterior margin is eroded, the presence of a cervical scute can be confirmed (Fig. 2B). The cervical is probably longer than wide. Throughout the preserved parts, the costo-peripheral suture coincides with the pleuro-marginal sulcus, which is a typical character of most testudinids (see Lapparent de Broin et al., 2006, and references therein).

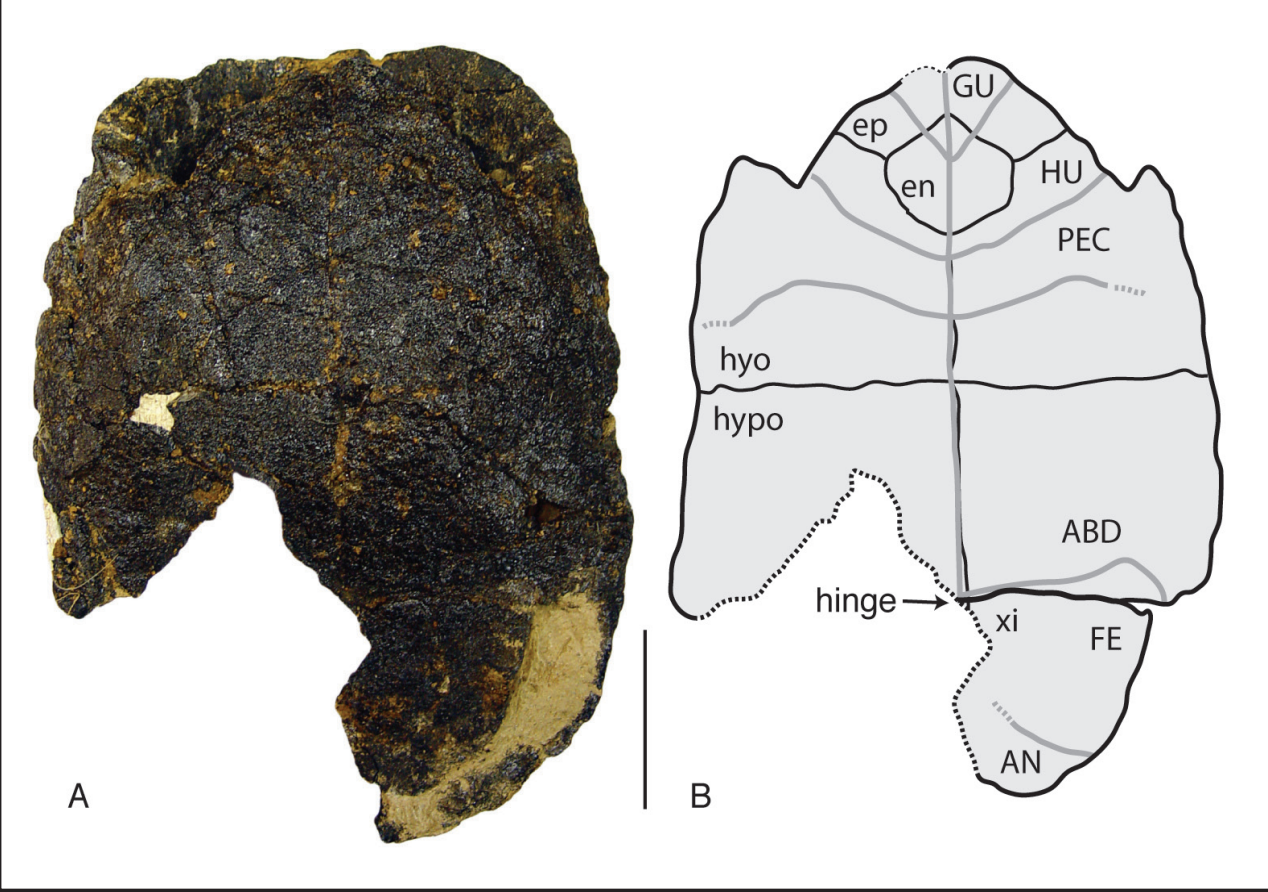

Fig. 3. The plastron of the specimen of Testudo cf. graeca (LGPUT PLD 70) from the Late Miocene of Platania (Drama basin, Northern Greece), A, ventral view. B, drawing of the ventral view. Sutures are indicated with black lines, sulci with grey lines. Scale bar equals $5 \mathrm{~cm}$.

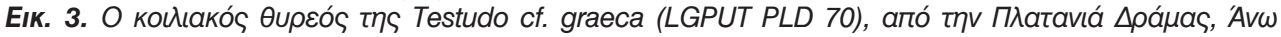

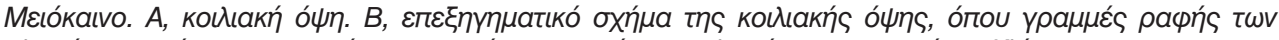

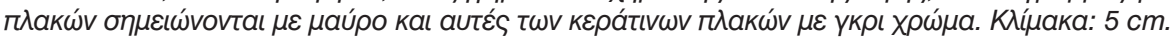


Plastron: Most of the plastron (LGPUT PLD 70) is preserved, whereas only the right xiphiplastron is missing (Fig. 3A, 3B). The epiplastra are short, forming a very thick epiplastral lip (Fig. $2 \mathrm{C}$ ) with a deep pocket (Fig. 2D). The epiplastral lip is convex. In ventral view, the entoplastron is hexagonal. Hyo- and hypoplastra are the largest plates of the plastron. The medial part of the hyo- and hypoplastra is flat, indicating that the Platania tortoise is a female individual; normally, the male individuals show a deep concavity in their plastron. Xiphiplastra are longer than wide, representing the entire length of the posterior lobe. Posteriorly, the xiphiplastra show a very wide and short anal notch. The gular scutes are longer than wide, covering the medial part of the epiplastra and the anterior part of the entoplastron. The shape of the humero-pectoral sulcus is wide $\mathrm{V}$ shaped, located on the hypoplastra and being posterior to the entoplastron. The pectoro-abdominal sulcus is sigmoidal in shape, being concave in the medial part and convex laterally. The pectorals are short and wide, whereas the ab- dominals are the longest scutes in the plastron. The abdomino-femoral sulcus coincides medially with the hypo-xiphiplastral suture; laterally it is located in the posterior parts of the hypoplastra, being strongly convex. This morphology, which is noted in many extant and extinct Testudo s.s., indicates the presence of a movable hinge between the hypo- and xiphiplastra. The anals are longer medially and shorter laterally, while the femoro-anal sulcus is slightly concave on each side.

Appendicular skeleton: Only the proximal part of the right humerus (LGPUT PLD 71) is preserved (Fig. 4A-C). This element has been recovered in anatomical position, resting on the visceral side of the right epiplastron. The trochanters are partially preserved, but they are developed sub-parallel to each other. The humeral head is spherical. From the preserved part we can estimate the shaft of the bone that is curved. In general, the morphology of the PLD humerus is similar to the morphology of the extant Testudo graeca.
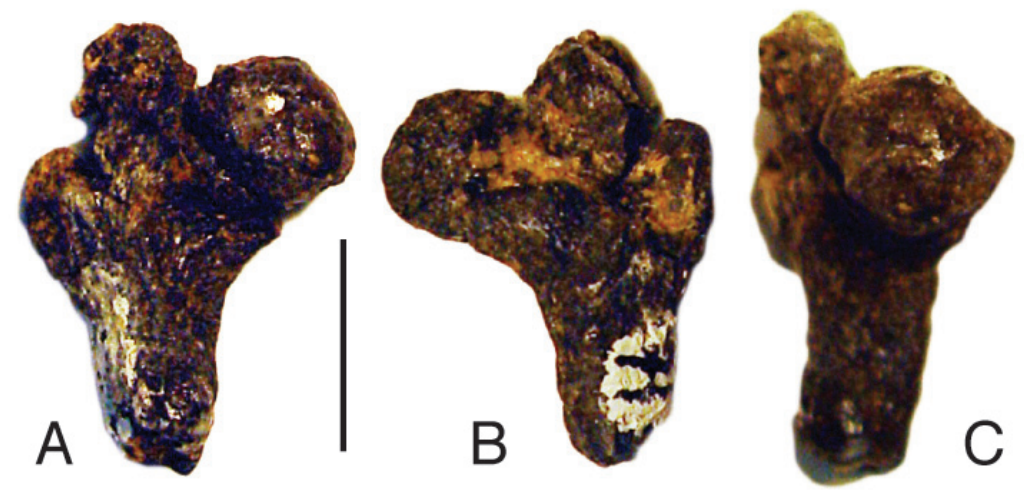

Fig. 4. Proximal part of the right humerus (LGPUT PLD 71) of the specimen of Testudo cf. graeca from the Late Miocene of Platania (Drama basin, Northern Greece). A, posterior, B, anterior, and C, dorsal views. Scale bar equals $1 \mathrm{~cm}$.

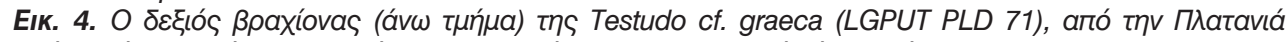

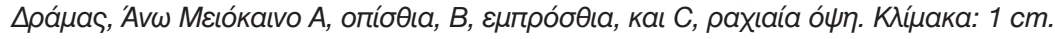




\section{Comparisons}

Recent studies have attempted to summarize the published chelonian fossil record of Greece (Lapparent de Broin, 2002; Mueller-Töwe et al., 2011; Georgalis and Kear, 2013). Most of their concluding remarks, however, about the faunal composition, temporal and geographical distribution are hindered by the fact that they are based mainly on published data from old and outdated papers. The discovery of new specimens, like the Platania tortoise, is necessary for the better knowledge of the Greek chelonian fauna and provides new information, allowing the revision of previously published specimens. In this paper we report the first finding of Testudo cf. graeca from the Late Miocene of Greece, which joins the other hinged testudinid, Testudo marmorum Gaudry, 1862-1867, increasing the specific diversity during Miocene. This new specimen has been directly compared with all published Testudo s.s. material from the Neogene of Greece, and the main comparative conclusions are listed below.

Testudo marmorum was described from the Late Miocene site of Pikermi by Gaudry during 1862-1867, based on two specimens (one of them, MNHN PIK 3683 , is labeled as TYPE), which are the first testudine fossils described from Greece. Additional material from Pikermi (AMPG collection) have been also attributed to T. marmorum by Bachmayer and Symeonidis (1970). This species belongs to the Testudo s.s. lineage (sensu Lapparent de Broin et al., 2006) due to the presence of a hypo-xiphiplastral hinge, which is preserved in the one of the Gaudry's specimens (the other does not preserve the plastron). This taxon was considered as member of the Testudo marginata group by Lap- parent de Broin (2001, 2002). Georgalis and Kear (2013) explain this due to the "[...] carapace the flares posteriorly [...]" (Georgalis and Kear, 2013:304). This flange of the carapace should not be observed in the posterior peripherals 8-10 (as it is noted in Fig. 1C, G in Georgalis and Kear, 2013), since these parts always display some degree of flaring in Testudo sensu lato. Instead, the characteristic posterior flaring of $T$. marginata is found in the posterior region of the carapacial margin (peripherals 11 and pygal), in contrast with the other Testudo, where it is bended inwards and it is stronger in male individuals. In the known specimens of $T$. marmorum (MNHN and AMPG) the pygal region is not preserved. Therefore, $T$. marmorum should be associated with T. marginata only because the posterior carapace widens right after the bridge, as it is observed in one of the type specimens of Gaudry (but note that this specimen is deformed). This morphology is not observed in the Platania testudinid, and therefore is clearly different from $T$. marmorum.

The Platania tortoise is also different from the new testudinid from Ravin de la Pluie, lower Axios valley (preliminary reported by Garcia et al., 2011), since it is lacking the characteristic features of the Axios new tortoise (tectiform shell shape, deeply indented nuchal border). Garcia et al. (2011) also mention this specimen is the oldest terrestrial Testudinidae from Greece. Although it is likely the oldest record of Testudo s.s. in Greece, the findings from the Middle Miocene of Chios Island (Paraskevaidis, 1955) are actually the oldest record of a terrestrial tortoise. These specimens, however, have been lost during the Second World War (footnote in Paraskevaidis, 1955; Markus Moser, personal communication). 
The best preserved fossil specimen of $T$. graeca from Greece is known from the Pliocene deposits of Megalo EmvoIon (Bachmayer et al., 1979). This specimen (NHMW 1980z0069/0000) is an entirely complete shell, with sediment preserved interiorly. It belongs to a male individual, as it is inferred by the deep plastral concavity. It has been correctly attributed to $T$. graeca by Bachmayer et al. (1979) based on the general morphology and the presence of a hypoxiphiplastral hinge. In this case, the mobile xiphiplastra have been moved from their natural position and they are resting disarticulated on the posterior part. Generally, the Platania specimen is similar in morphology with the Megalo Emvolon specimen. Small differences, like the wider and longer nuchal, and the almost rhomboid entoplastron of the NHMW specimen, could lie within the range of the intraspecific variation and/or sexual dimorphism of T. graeca, as it found in other closely related Testudo s.s. taxa (see Perälä, 2002 for example).

Other Greek fossil specimens that could be attributed to $T$. graeca are: some specimens of small tortoises from Thessaloniki (in Arambourg and Piveteau, 1929) and a partial shell from Lesvos (in Lapparent de Broin, 2002). The former material, which have been only mentioned, but not described in detail, by Arambourg and Piveteau (1929), are of uncertain age (Late Miocene to Pliocene) since their precise locality is not known (see discussion in Vlachos et al., in press). They consist of several fragments of carapace and plastron (MNHN collection), whose morphology (e.g. pygal region curved inwards; thick epiplastral lip; anterior entoplastron covered by gulars) is similar with the Testudo graeca fossil and extant exam- ined in this study. The Lesvos specimen has been figured in Lapparent de Broin (2002) and was identified as Testudo cf. graeca ibera, based on the presence of the hinge, and the femoral's morphology. Our observations on these specimens did not reveal any notable differences from the Platania specimen.

Finally, another taxon that is important to use for comparison is Testudo amiatae Pantanelli, 1892, from the Upper Miocene of Tuscany (Italy). It has been found in Greece for the first time by del Campana (1917), from Capundjlar, near Thessaloniki. The name of the locality is actually the old Turkish name of the present-day area of Pylaia. This locality is also known as Allatini, a name that is commonly used in more recent publications. The clay deposits of this area are not easy to be located today, not only because of the extensive domestic areas but also because most of these sediments have been exploited for clay production in the past. In this area, remains of Trilophos (Latest Miocene) and Gonia (Pliocene) formations (sensu Syrides, 1990) have been located, but the stratigraphic position of the del Campana (1917) specimen remains uncertain. Its geological age could be only inferred as Latest Miocene-Early Pliocene. In the overview of Georgalis and Kear (2013) there is confusion about the Greek material attributed to this taxon. They state that "Testudo amiatae [...] Allatini, near Thessaloniki (Campana, 1917) [...] the only known Greek specimen (Fig. 4D, E) consisting of a poorly-preserved shell (AMPG(y) 1917/1970/2) [...]" (Georgalis and Kear, 2013:304), clearly believing that the specimen described by del Campana (1917) is the AMPG specimen. Actually, the specimen described by del Campana in 1917 is part of the exhibition and 
collections of IGF (IGF 11602), and the AMPG material is another specimen which was described later by Bachmayer and Symeonidis (1970). The IGF specimen is almost complete, while the AMPG specimen is only partial, but they are both similar and belong to the same taxon. They have been referred to T. amiatae by del Campana (1917) and Bachmayer and Symeonidis (1970), a Testudo s.l. species without a hypoxiphiplastral hinge. Our study of the IGF specimen revealed that a hinge is indeed present and therefore the attribution to $T$. amiatae is not correct. The morphology of both specimens is within the variability observed in the Testudo graeca group, and is similar with the Platania and Megalo Emvolon specimens. Therefore, these two specimens from Allatini could be, preliminary, referred to the Testudo graeca lineage as well. As a result, $T$. amiatae is not part of the Greek fossil chelonian fauna, and all the Testudo specimens from Late Miocene-Pliocene of Greece can be attributed to the Testudo sensu stricto. Interestingly, the presence of fossil Testudo s.l. (i.e. without the hypo-xiphiplastral hinge) is yet to be confirmed in Greece. Recently, Gmira et al. (2013) described Testudo oughlamensis Gmira, Lapparent de Broin, Geraads, LeFèvre, Mohib, Raynal, 2013, a new species of Testudo s.s. from the Pliocene of Ahl al Ouglam (Morocco). The Platania specimen differs from the Moroccan taxon on the much weaker nuchal notch, the absence of pointed anterior peripherals, the shorter epiplastral lip, and the shorter pectorals laterally. Further differences could be noted on the hinge area. In T. oughlamensis, the abdomino-femoral sulcus is located anterior to the hypo-xiphiplastral suture medially, whereas in the Platania specimen they medially coincide.

Summarizing, the comparisons above indicate that the Platania specimen is consistent with the morphology of $T$. graeca lineage (based on the evident hypo-xiphiplastral hinge and the pygal which is curved inwards). The limited information, however, on the morphology of the carapace of this specimen does not allow a confident assessment to this taxon. Based on the preserved parts, the Platania tortoise can be identified for the moment as Testudo cf. graeca, but is clearly different from the other taxa found in the Late Miocene ( $T$. marmorum and the new testudinid from Ravin de la Pluie).

\section{Discussion}

Following Fritz et al. (2007), the extant Testudo s.s. species in Greece (exc. T. marginata) can be referred to $T$. graeca ibera. This taxon can be found in Southeast Europe, western Asia Minor, Black sea coast and central Caucasus region. Fossil Testudo s.s. specimens are very difficult to be confidently identified into the subspecies level in many cases, like in $T$. g. ibera, because the differences are found on characters that are not preserved in fossils (e.g. coloration). Fritz et al. (2009) used Testudo burtschaki from Caucasus area (Upper Sarmatian-Lower Maeotian), to estimate the split between $T$. graeca and the clade grouping T. kleinmanni and T. marginata between $10.0-8.0 \mathrm{Ma}$, with the minimum divergence between $T$. graeca subspecies estimated much later, in the Pliocene. However, Delfino et al. (2009:851) have questioned the inclusion of $T$. burtschaki in the Testudo s.s. group, since this taxon has no plastral hinge, stressing the importance of detailed anatomical descriptions of extant Testudo species. Fritz et al. (2009) 
mention also Testudo eldarica from the slightly younger strata from Azerbaijan (Maeotian), as one of the oldest members of the $T$. graeca group, following Danilov (2005). These two taxa from Caucasus area need revision before they are used as molecular clock estimates, following the recommendations by Parham et al. (2012) for the use of fossils for temporal calibrations. The same is true for most Late Miocene Testudo specimens, because most of the available information is outdated.

One of the major problems of the use of fossils in such calibrations is the incorrect placement of a specimen as the oldest record of this clade (Parham et al., 2012:348). The Platania tortoise could be one of the oldest $T$. graeca in Greece and South Balkans, but more specimens are needed, together with the detailed study of the associated fauna that is going to provide more accurate information on the geological age of the specimen. Future research should focus in the clarification of the taxonomic status of the Late Miocene - Pliocene Testudo s.s. specimens of the circum-Mediterranean area. Many specimens are known. In Italy, the only record of Testudo s.s. is Testudo pecorinii Abbazzi, Carboni, Delfino, Gallai, Lecca and Rook, 2008, from the Late Pliocene of Capo Mannu. Unfortunately, the preserved parts in the holotype of $T$. pecorinii do not allow further comparison with the Platania specimen. In Western Europe, Testudo graeca has been proposed as introduced by humans in Holocene times (Moralez-Pérez et al., 2009). In North Africa, the oldest reliable record of a hinged Testudo is from Ahl Al Oughlam (Morocco, Pliocene, see Gmira et al., 2013) and possibly from Ichkeul (Tunisia, Pliocene), probably originated from the Palaearctic (Lapparent de Broin, 2000). Future research should focus on the detailed description of the hinged specimens from the area between Caucasus, South Balkans and Turkey, to provide new information on the probably oldest records of Testudo sensu stricto. In Turkey for example, Staesche et al. (2007) reported the presence of Testudo sp. cf. graeca since MN6 (Astaracium) from Ankara-Kalecik-Çandir. This material is not figured to be able to confirm their identification, whereas the figured specimens from other Turkish localities could be attributed to Testudo sensu lato.

Finally, the Platania specimen is useful for the estimation of the paleozoogeographical range of the genus Testudo in Greece. The Platania tortoise is the northernmost chelonian finding, extending the range of Testudo to Drama basin. Before this discovery, the northernmost finding was from Xerias locality, in Kavala region of Pleistocene age (Tsoukala et al., 2011). This material consists of a compressed shell of Testudo sp. which, based on the presence of hypo-xiphiplastral hinge and widened posterior carapace, could be associated with the marginated tortoise and not with $T$. graeca.

\section{Conclusions}

Platania is a new Late Miocene locality from Drama basin (Northern Greece) and one of the few Neogene localities of Eastern Macedonia and Thrace. In addition to the numerous fossil mammal specimens that were recovered on a single excavation campaign, a wellpreserved partial shell of a tortoise has been found. The detailed study of this specimen, as well as the comparison with known testudinids from Greece, allowed us to identify this as Testudo cf. 
graeca. This could be the oldest record of this taxon in South Balkans, which so far has been only identified in the Pliocene-Early Pleistocene of Greece, and one of the oldest records of the spurthighed tortoise in the Mediterranean area. The study of this specimen triggered the revision of the two known specimens of Testudo amiatae from Allatini, near Thessaloniki, showing that these specimens are actually members of the $T$. graeca lineage. Testudo amiatae is therefore not present in Greece. Furthermore, the specific diversity of the Testudo s.s. lineage in Miocene increases, since so far only Testudo marmorum has been identified in Late Miocene deposits. Finally, this specimen extends northwards the palaeozoogeographical range of Testudo in Greece.

\section{Acknowledgments}

We would like to thank the mayor of the municipality of Paranesti, Mr. N. Kagiaoglou and the municipal council for their support during the July 2013 excavation. Mr. K. Eleftheriadis and Mr. Th. Fountoukidis who donated fossils which have been previously discovered. Mrs V. Puliudi for information which led to the discovery of the site. A. Bougeli, V. Makridis, E. Samartzidou, N. Tsigkirliotis, and Al. Xafis, for helping with the excavation and preparation of the fossils. J. Sterli for assistance with the study of the IGF specimen and for comments on an earlier version of the manuscript. Ass. Prof. Dr N. Kantiranis for his help on the description of the Platania sediments; I. M. Zougrou, PhD candidate who provided information on the structural analysis of the PLD fossil material. We deeply thank the reviewers A. Pérez-Garcia and M. Delfino, for valuable comments that greatly improved the manuscript and A. Zam- betaki for editorial work. For facilitating access to study comparative material we would like to deeply thank $\mathrm{G}$. Theodorou and S. Roussiakis (AMPG), E. Cioppi (IGF), R. Allain and B. Battail (MNHN), M. Harzhauser and U. Göhlich (NHMW), T. Kotsakis (University Roma Tre, Italy). EV was supported by a scholarship of the Research Committee of Aristotle University of Thessaloniki (50141/372029 and 50141/372031).

\section{References}

Abbazzi, L., Carboni, S., Delfino, M., Gallai, G., Lecca, L., Rook, L., 2008. Rivista Italiana di Paleontologia e Stratigrafia. 114, 119-132.

Arambourg, C., Piveteau, J., 1929. Les Vertébrés du Pontien de Salonique. Annales de Paléontologie, 18, 57139.

Athanassiou, A. (in press). Anancus arvernensis (Proboscidea, Mammalia) from Kallíphytos (E. Macedonia, Greece), with a revision of existing samples from Greece. Volume of $A b$ stracts of the VIth International Conference on Mammoths and their Relatives, May 2014, Greece.

Bachmayer, F., Symeonidis, N., 1970. Die Fossilen Schildkrötenreste des Geologisch-Paläontologischen Institutes der Universität von Athen, Annales Géologiques des Pays Helléniques, 22, 227-246.

Bachmayer, F., Mlynarski, M., Symeonidis, N., 1979. Fossile Schildkröten aus dem Pliozän von Megalo Emvolo (Karaburun) bei Saloniki (Griechenland). Annales Géologiques des Pays Helléniques, 29, 267-276.

Campana, del D., 1917. Resti di Testudo nel Miocene superiore di Capudjlar presso Salonicco. Bolletino della Società Geologica Italiana, 34, 6978. 
Danilov, I., 2005. Die fossilen Schildkröten Europas, in U Fritz (ed.) Handbuch der Reptilien und Amphibien Europas. Schildkröten (Testudines) II. (Cheloniidae, Dermochelyidae, Fossile Schildkröten Europas). Wiebelsheim, Germany, AULA-Verlag, 329-448 pp.

Delfino, M., Chesi, F., Fritz, U., 2009. Shell morphology of the Egyptian tortoise, Testudo kleinmanni Lortet, 1883, the osteologically least-known Testudo species. Zoological Studies, 48(6), 850-860.

Fritz, U., Hundsdörfer, A.K., Široký, P., Auer, M., Kami, H., Lehmann, J., Mazanaeva, L.F., Türkozan, O., Wink, M., 2007. Phenotypic plasticity leads to incongruence between morphology-based taxonomy and genetic differentiation in western Palaearctic tortoises (Testudo graeca complex; Testudines, Testudinidae). Amphibia-Reptilia, 28, 97-121.

Fritz, U., Harris, J.D., Fahd, S., Rouag, R., Gracià Martinez, E., Giménez Casalduero, A., Široký, P., Kalboussi, M., Jdeidi, T., Hundsdörfer, A.K., 2009. Mitochondrial phylogeography of Testudo graeca in the Western Mediterranean: Old complex divergence in North Africa and recent arrival in Europe. Amphibia- Reptilia, 30, 63-80.

Garcia, G., Lapparent de Broin, F. de, Bonis, L. de, Koufos, G.D., Valentin, X., Kostopoulos, D., Merceron, G., 2011. A new terrestrial Testudinidae from the Late Miocene hominoid locality "Ravin de la Pluie" (Axios Valley, Macedonia, Greece). Volume of Abstracts of the 9th EAVP, Herakleion, Crete, Greece, June 2011, p.26.

Geraads, D., Tsoukala, E. Spassov, N., 2007. A skull of Ancylotherium (Chal- icotheriidae, Mammalia) from the late Miocene of Thermopigi (Serres, N. Greece), and the relationships of the genus. Journal of Vertebrate Palaeontology, 27(2), 461-466.

Georgalis, G., Kear, B., 2013. The fossil turtles of Greece: an overview of taxonomy and distribution. Geobios, 46, 299-311.

Gmira, S., Broin, F. D. L. D., Geraads, D., Lefèvre, D., Mohib, A., \& Raynal, J. P. (2013). Les Tortues Du Pliocène d'Ahl al Oughlam (Casablanca, Maroc) et De Localités Mio-Pliocènes Avoisinantes. Geodiversitas, 35(3), 691-733.

Joyce, W., Parham, J., Gauthier, J., 2004. Developing a protocol for the conversion of rank-based taxon names to phylogenetically defined clade names, as exemplified by turtles. Journal of Paleontology, 78(5), 989-1013.

Kostopoulos, D.S., 1997. The PlioPleistocene artiodactyls from Macedonia, Greece: 2. The fossiliferous locality of Volakas, VOL (Volakas basin, Drama, NE Greece). Paleontologia i Evolució, 30-31, 83-92.

Koufos, G. D., 1981. A new late Pleistocene (Würmian) mammal locality from the basin of Drama (Northern Greece). Scientific Annals, Faculty of Physics and Mathematics, University of Thessaloniki, 21, 129-148.

Koufos, G. D., Vlachou, T., 1997. Equus stenonis from the middle Villafranchian locality of Volax (Macedonia, Greece). Geodiversitas, 19, 641-657, Paris.

Lapparent de Broin, F. de, 2000. African chelonians from the Jurassic to the Present: phases of development and preliminary catalogue of the fossil record. Palaeontologia Africana, 36, 43-82. 
Lapparent de Broin, F. de., 2001. The European turtle fauna from the Triassic to the Present. Dumerilia, 4(3), 155-217.

Lapparent de Broin, F. de, 2002. A giant tortoise from the Late Pliocene of Lesvos Island (Greece) and its possible relationships. Annales Géologiques des Pays Helléniques, 34, 99-130.

Lapparent de Broin, F. de, Bour, R., Perälä, J., 2006. Morphological definition of Eurotestudo: First part. Annales de Paléontologie, 92, 255-304.

Moralez-Pérez, J. V., Sanchis Serra, A., 2009. The Quaternary fossil record of the genus Testudo in the Iberian Peninsula. Archaeological implications and diachronic distribution in the western Mediterranean. Journal of Archaeological Science, 36,11521162.

N.I.G.M.R., 1974. Geological map, Krinidhes sheet, 1:50.000. Mapping by P. Kronberg, during 1962-1970.

Mueller-Töwe, I., Kjeldahl-Vallon, T., Milàn, J., Vallon, L., Theodorou, G., Lindgren, J., Roussiakis, S., Bromley, R., 2011. First chelonian eggs and carapace fragments from the Pliocene of Rhodes, Greece. N. Jb. Geol. Paläont. Abh., 262, 309-322.

Paraskevaidis, I., 1955. Zwei schildkrötenreste aus dem obermiozän von Chios. Annales Géologiques des Pays Helléniques, 6, 133-141.

Parham, J. F., Donoghue, P. C. J., Bell, C.J., et al. (22 co-authors), 2012. Best practices for using paleontological data for molecular divergence dating analyses. Systematic Biology, 61, 346-359.

Perälä, J. (2002). Morphological variation among Middle Eastern Testudo graeca L., 1758 (sensu lato), with a focus on taxonomy. Chelonii, 3, 78108.

Staesche, K., Karl, H. V., Staesche, U., 2007. Fossile Schildkröten aus der Türkei, in Staesche U. (ed.), Fossile Schildkröten aus drei Kontinenten, Geologisches Jahrbuch, Hannover, Germany, 98, 91-149 pp.

Syrides, G. E., 1990. Lithostratigraphic, biostratigraphic and palaeogeographic study of the NeogeneQuaternary sedimentary deposits of Chalkidiki Peninsula, Macedonia, Greece. Ph.D. dissertation, Aristotle University of Thessaloniki, School of Geology, Scientific Annals 1(11), 243 pp. [Greek, with English summary].

Trantalidou, K., 2013. On the banks of the river Angitis: Environmental data from the basin of Drama in prehistoric times. Proceedings of the E' Scientific Meeting, Drama, 2006, volume E1, 41-156. [Greek, with English summary].

Tsoukala, E., Mol, D., Pappa, S., Vlachos, E., Logchem, W., Vaxevanopoulos, M., Reumer, J., 2011. Elephas antiquus in Greece: New Finds and a reappraisal of older material (Mammalia, Proboscidea, Elephantidae). Quaternary International, 245, 339-349.

Vlachos, E., Tsoukala, E., Corsini, J., in press. Cheirogaster bacharidisi sp. nov., a new species of a giant tortoise from the Pliocene of ThessaIoniki (Macedonia, Greece). Journal of Vertebrate Palaeontology.

Zangerl, R., 1969. The turtle shell, in A. d'A. Bellairs and T. S. Parsons (eds.), The Biology of the Reptilia 1, Morphology A. Academic Press, London and New York, 311-339 pp. 